\title{
Plant Community and Soil Environment Response to Summer Fire in the Northern Great Plains
}

\author{
Lance T. Vermeire, ${ }^{1}$ Jessica L. Crowder, ${ }^{2}$ and David B. Wester ${ }^{3}$
}

Authors are ${ }^{1}$ Ecologist, US Department of Agriculture-Agricultural Research Service, Fort Keogh Livestock and Range Research Laboratory, 243 Fort Keogh Rd, Miles City, MT 59301, USA; ${ }^{2}$ Policy Analyst, Wyoming Department of Agriculture, Natural Resources \& Policy, 2219 Carey Ave, Cheyenne, WY 82002 , USA; and ${ }^{3}$ Professor, Department of Natural Resources Management, Goddard Building, Texas Tech University, Box 42125, Lubbock, TX 79409, USA.

\begin{abstract}
Fire is an important process in many ecosystems, especially grasslands. However, documentation of plant community and soil environment responses to fire is limited for semiarid grasslands relative to that for mesic grasslands. Replicated summer fire research is lacking but necessary because summer is the natural fire season and the period of most wildfires in the western United States. We evaluated summer fire effects on soil temperature, soil moisture, aboveground biomass, root biomass, and functional group composition for $2 \mathrm{yr}$ in semiarid $\mathrm{C}_{3}$-dominated northern Great Plains. Following pre-treatment measures, four 0.75-ha sites were burned during August for comparison with nonburned sites, and the experiment was repeated the next year on adjacent sites to assess weather effects. Soils were about $0.5^{\circ} \mathrm{C}$ cooler on burned sites in the first experiment and similar in the second. Burned sites were consistently $1 \%$ drier than nonburned sites. Litter was reduced by fire but did not account for changes in soil moisture because differences occurred before the growing season. Current-year aboveground biomass and root biomass were similar between treatments, indicating productivity was resistant to summer fire. Perennial $\mathrm{C}_{3}$ grasses increased in dominance because of positive biomass responses to fire for all but the bunchgrass, Hesperostipa comata, and a reduction of annual grasses. Perennial $\mathrm{C}_{4}$ grasses were unaffected by summer fire. $\mathrm{H}$. comata was resilient, with biomass on burned sites equaling nonburned sites the second growing season. Biomass was more responsive to precipitation than fire, and the fireinduced changes in species composition suggest exclusion of fire may be a greater disturbance than summer fire.
\end{abstract}

\section{Resumen}

El fuego es un proceso importante en muchos ecosistemas, especialmente en praderas. Sin embargo, la documentación de respuestas de la comunidad vegetal y del ambiente edáfico al fuego en pastizales semiáridos es limitada comparado con praderas mesofíticas. Ensayos replicados investigando los fuegos de verano son escasos pero necesarios dado que el verano es la estación natural de ocurrencia de la mayoría de los incendios en el oeste de los Estados Unidos. Evaluamos los efectos de quemas de verano sobre la temperatura del suelo, la humedad del suelo, la biomasa aérea, la biomasa radicular, y la composición de grupos funcionales durante dos años en pastizales semiáridos dominados por especies $\mathrm{C}_{3}$ en el norte de las Grandes Planicies de América del Norte. Luego de mediciones pre-experimentales, cuatro sitios de 0,75 ha fueron quemados durante el mes de Agosto para compararlos con sitios que no fueron quemados y el experimento se repitió al año siguiente en sitios adyacentes para evaluar efectos meteorológicos. Los suelos de los sitios quemados estuvieron $0,5^{\circ} \mathrm{C}$ más frescos en el primer experimento y de modo similar en el segundo. Los sitios quemados estuvieron consistentemente $1 \%$ más secos que los sitios no-quemados. El fuego redujo la cantidad de broza, pero la misma no explicó las diferencias en humedad edáfica porque dichas diferencias ocurrieron antes de la estación de crecimiento. El crecimiento del año de biomasa aérea y la biomasa radicular fue similar entre tratamientos, indicando que la productividad resistió el fuego de verano. Los pastos perennes $\mathrm{C}_{3}$ aumentaron en dominancia debido a respuestas positivas al fuego en producción de biomasa para todas las especies excepto el pasto Hesperostipa comata, y una reducción en las especies anuales. Los pastos perennes $\mathrm{C}_{4}$ no fueron afectados por los fuegos de verano. $\mathrm{H}$. comata demostró resiliencia con biomasas iguales en sitios quemados y no-quemados en la segunda estación de crecimiento. La biomasa respondió más a la precipitación que al fuego y los cambios en la composición de especies inducida por el fuego sugieren que la exclusión del fuego podría ser un disturbio mayor que los fuegos de verano.

Key Words: drought, prescribed burning, productivity, rangeland, semiarid grassland

Mention of any trade name or proprietary product does not constitute a guarantee or warranty by the authors or US Department of Agriculture-Agricultural Research Service (USDA-ARS), nor does it imply the approval of these products to the exclusion of others.

The USDA-ARS, Northern Plains Area, is an equal opportunity/affirmative action employer, and all agency services are available without discrimination.

At the time of research, Crowder was Research Assistant, Dept of Range, Wildlife and Fisheries, Texas Tech University, Lubbock, TX 79409, USA.

Correspondence: Lance Vermeire, USDA-ARS, Fort Keogh Livestock and Range Research Laboratory, 243 Fort Keogh Rd, Miles City, MT 59301, USA. Email: Lance.Vermeire@ ars.usda.gov

Manuscript received 22 March 2010; manuscript accepted 26 September 2010.

\section{INTRODUCTION}

Fire is an important process in numerous terrestrial ecosystems, particularly grasslands. Fires occurring during periods when wildfires are most frequent may be more detrimental to plant communities because fuel and weather conditions create greater fire intensity than fires occurring outside the natural fire season. Warmer temperatures, drier fuel and air, and greater fuel loads each increase fire intensity, and these factors converge seasonally in most grasslands worldwide (Govender et 
al. 2006). However, native flora evolved under this regime, and plants may be physiologically less susceptible to fire damage during the natural fire season because of heat- or droughtinduced quiescence.

Although fire frequency generally decreases as regional climate becomes drier and fuel loads decrease, fire is common in semiarid grasslands such as the western Great Plains (Thonicke et al. 2001), and its ecological effects need to be better explained. This is particularly true regarding summer fire because more than $70 \%$ of the wildfires in the western United States occur during July and August (Higgins 1984; Westerling et al. 2003). Summer-prescribed fire has been recommended to mimic natural fire regimes and increase diversity (Howe 1994), but action on this suggestion has been delayed, in part, by insufficient plant response data. Research examining ecological responses to fire is often limited by the fact that the natural fire season coincides with the period of greatest fire danger. Therefore, research has focused mostly on prescribed fires conducted outside the primary fire season and on wildfires lacking pre-fire data and replication. Herbivore attraction to burned sites (Vermeire et al. 2004) and potential effects of selective use on plant response have further complicated interpretation of results from wildfire studies (Engle and Bidwell 2001).

Some replicated summer fire research has been conducted in tallgrass prairie (Ewing and Engle 1988; Howe 1995; Engle et al. 1998) and $\mathrm{C}_{4}$-dominated sites in southern mixed and shortgrass prairies of the Great Plains (Brockway et al. 2002; Ansley et al. 2006; Ford and Johnson 2006; Castellano and Ansley 2007). Response of $\mathrm{C}_{3}$-dominated rangeland to summer fire is limited to wildfires (Clarke et al. 1943; Dix 1960; Coupland 1973; de Jong and MacDonald 1975; ErichsenArychuk et al. 2002) and the mesic transition zone between mixed and tallgrass prairie (Steuter 1987; Biondini et al. 1989). Summer fire effects likely differ between regions because dominant plants are typically active during summer in warmer and wetter regions and quiescent in cooler and drier $\mathrm{C}_{3}$ dominated grassland.

Fire effects on soil temperature and moisture are important in semiarid regions because both factors affect productivity, and these grasslands are generally water limited. Removal of litter and plant cover increase solar radiation at the soil surface and increase daytime temperatures (Hulbert 1969; Sharrow and Wright 1977; Ewing and Engle 1988; Bremer and Ham 1999; Vermeire et al. 2005), but the same loss of insulation should allow more heat loss at night, causing greater daily temperature fluctuations on burned sites. Drier soils on burned sites have been attributed to increased evapotranspiration with greater green leaf area (Bremer and Ham 1999) and to reduced water capture through greater hydrophobicity and snow loss (Trlica and Schuster 1969; de Jong and MacDonald 1975; DeBano 2000).

Research to date suggests summer fire reduces productivity in dry northern mixed prairie (Dix 1960; Erichsen-Arychuk et al. 2002) but has no effect on productivity in mesic northern mixed prairie (Steuter 1987). However, summer fire has promoted $\mathrm{C}_{3}$ plant production or increased its relative contribution to biomass through reduction of $\mathrm{C}_{4}$ grasses in tallgrass and mesic mixed prairie (Steuter 1987; Howe 1995; Engle et al. 1998). Where perennial $C_{3}$ grasses are more productive than coexisting $\mathrm{C}_{4}$ and annual grasses, such a shift may be expected to yield greater productivity. Productivity may ultimately depend on post-fire precipitation because of the strong influence of spring moisture on rangeland biomass in the northern Great Plains (Smart et al. 2007; Vermeire et al. 2008).

Our objective was to assess summer fire effects on soil environment and aboveground and belowground biomass relative to nonburned sites in semiarid $\mathrm{C}_{3}$-dominated grassland. Treatments were summer fire and no fire assigned in a completely randomized design with the experiment repeated in consecutive years to assess weather effects. Plant community responses were examined in the first and second growing seasons after treatment to evaluate the ability to maintain productivity and species composition (resistance sensu Grime 2001, p. 335) and regain characteristics of the nonburned sites (resistance sensu Grime 2001, p. 335) following summer fire. We hypothesized that summer fire would 1) reduce daily minimum soil temperature and increase daily maximum soil temperature by reducing insulating effects of litter, 2) reduce soil water content, 3) reduce standing crop (current-year and old vegetation), 4) increase current-year biomass, and 5) increase relative biomass composition of $\mathrm{C}_{3}$ perennial grasses.

\section{MATERIALS AND METHODS}

\section{Study Site}

Research was conducted in semiarid mixed prairie on the Fort Keogh Livestock and Range Research Laboratory located near Miles City, Montana, USA (lat $46^{\circ} 24^{\prime} \mathrm{N}$, long $105^{\circ} 56^{\prime} \mathrm{W}$; $815 \mathrm{~m}$ above sea level). Average annual precipitation is 339 mm, with 75\% occurring April through September. Precipitation effects on current-year biomass are generally greatest during April and May (Heitschmidt and Vermeire 2005). Temperatures range from $38^{\circ} \mathrm{C}$ during summer to $-40^{\circ} \mathrm{C}$ during winter. The freeze-free period ranges from $110 \mathrm{~d}$ to $135 \mathrm{~d}$.

The study site is composed of gently rolling uplands on primarily Pinehill loam soil (Fine, montmorillonitic Typic Eutroboralfs) interspersed with a Pinehill-Absher complex. Absher soil is a clay loam (Fine, smectitic, frigid Leptic Torrertic Natrustalfs). Both soils are deep and well drained. The site was not grazed by livestock during the study period, but cattle grazed the site for decades at a moderate stocking rate of about 1 animal unit month $\cdot \mathrm{ha}^{-1}$ until May 2003. Current-year biomass ranged from 460 to $1330 \mathrm{~kg} \cdot \mathrm{ha}^{-1}$ during the $10 \mathrm{yr}$ preceding this research. Vegetation was dominated by perennial $\mathrm{C}_{3}$ graminoids needle-and-thread (Hesperostipa comata [Trin. \& Rupr.] Barkworth), western wheatgrass (Pascopyrum smithii [Rydb.] A. Löve), threadleaf sedge (Carex filifolia Nutt.), and Sandberg bluegrass (Poa secunda $\mathrm{J}$. Presl), and the perennial $\mathrm{C}_{4}$ grass blue grama (Bouteloua gracilis [Willd. Ex Kunth] Lag. Ex Griffiths). Annual grasses were Japanese brome (Bromus japonicus Thunb.), cheatgrass (B. tectorum L.), and six weeks fescue (Vulpia octoflora [Walter] Rydb.). Fringed sage (Artemisia frigida Willd.) was the principal subshrub, with some large shrubs, Wyoming big sagebrush (Artemisia tridentata Nutt. subsp. wyomingensis Beetle \& Young) and silver sagebrush (Artemisia cana Pursh), present as well. The most common forbs were the annuals woolly plantain (Plantago patagonica 
Jacq.), field cottonrose (Logfia arvensis [L.] Holub), and pale madwort (Alyssum alyssoides L.) and the perennials scarlet globemallow (Sphaeralcea coccinea [Nutt.] Rydb.) and Hood's phlox (Phlox hoodii Richardson).

\section{Methods}

Summer fire effects were examined by randomly assigning summer fire and nonburned treatments to 0.75-ha plots $(75 \times 100 \mathrm{~m})$ within a 30 -ha pasture. The experiment was repeated the following year, and treatments were replicated four times each year for a total of 16 experimental units. Fires were applied to individual plots 29 August 2003 (Experiment 1) and 24 August 2004 (Experiment 2) using a ring fire method and $3-\mathrm{m}$ fuel breaks to mineral soil around the perimeter. Fuel loads were $1504 \mathrm{~kg} \cdot \mathrm{ha}^{-1}$ in 2003 , and fires burned with ambient temperature of $19.4^{\circ} \mathrm{C}$ to $21.1^{\circ} \mathrm{C}$, $42 \%$ to $50 \%$ relative humidity, and 5.6 to $14.8 \mathrm{~km} \cdot \mathrm{h}^{-1}$ winds. In 2004, fuel loads of $1569 \mathrm{~kg} \cdot \mathrm{ha}^{-1}$ were burned with ambient temperature of $22.8^{\circ} \mathrm{C}$ to $26.7^{\circ} \mathrm{C}, 22 \%$ to $34 \%$ relative humidity, and 8.0 to $30.6 \mathrm{~km} \cdot \mathrm{h}^{-1}$ winds. High fuel continuity allowed for complete fire coverage of all vegetated portions of each plot.

Response variables measured were soil temperature, soil moisture, standing crop, current-year aboveground biomass, species composition, litter mass, and root mass. Standing crop, litter mass, and root mass were measured before treatment and the following 2 yr. Soil moisture and soil temperature were measured the first year following treatment. Current-year biomass was not sorted from standing crop before treatment but was measured thereafter.

Soil temperature was measured using Watchdog 100 Series Waterproof Button Loggers (Spectrum Technologies, Plainfield, IL) from 1 April to 18 November in the year following fire. Two loggers were placed face up $10 \mathrm{~cm}$ belowground and $20 \mathrm{~m}$ apart using hand trowels. Logger locations were permanently marked with steel reinforcing bars. Prior to burial, loggers were programmed to record temperature every hour and were connected to the steel bar with $30 \mathrm{~cm}$ of $1 \mathrm{~mm}$ wire to facilitate retrieval. With approximately 80 days of storage capacity, data were downloaded in the field using a docking station and SpecWare 6.02 software (Spectrum Technologies, Plainfield, IL) in mid-June and early September each year. Loggers were reset and immediately reburied for continued data collection.

A TR 100 soil moisture probe with a 20 - $\mathrm{cm}$ wave guide (Dynamax Inc, Houston, TX) was inserted at a $60^{\circ}$ angle in each plot and buried just below the soil surface. Five probes were used in each plot during 2005. Probe cables were protected within capped, $2.5-\mathrm{cm}$ diameter by $3-\mathrm{m}-$ long polyvinyl chloride pipes on the soil surface. Soil water content was measured in the field by connecting the soil probe to a Tektronix 1502C Metallic Time Domain Reflectometry Cable Tester (Dynamax) connected to a laptop computer. Samples were collected every $2 \mathrm{wk}$ from 29 March to 24 November the year following fire. The software TACQbeta was used to calculate soil water content and is available as freeware at http://www.cprl.ars.usda.gov/programs/index.htm.

Each plot was sampled in mid-July using 30 randomly located $0.25-\mathrm{m}^{2}$ circular quadrats. Standing crop of grami- noids, forbs, and fringed sage were obtained by clipping to ground level. Litter, defined as detached plant material on the soil surface, was collected immediately after quadrats were clipped. Each sample was oven-dried to a constant weight at $60^{\circ} \mathrm{C}$ and weighed to the nearest $0.01 \mathrm{~g}$ to obtain mass estimates. Litter was heated to $550^{\circ} \mathrm{C}$ for $5 \mathrm{~h}$ in a muffle furnace, and ash weight was subtracted from dry weight to determine mass on an organic matter basis. Standing crop subsamples were separated into current and past years' growth and reweighed to determine current-year biomass as an estimate of productivity.

Twenty soil cores $(4.2 \mathrm{~cm}$ diameter $\times 30 \mathrm{~cm}$ deep $)$ were systematically sampled in each plot. Cores were individually bagged in the field, dried to a constant weight, and weighed to determine bulk density. Root samples were then separated from each core using a hydropneumatic root washer. Cleaned roots were dried to a constant weight at $60^{\circ} \mathrm{C}$ and weighed to the nearest $0.01 \mathrm{~g}$ to estimate root biomass.

Species composition was estimated using the dry-weight-rank method (Mannetje and Haydock 1968; Jones and Hargreaves 1979; Gillen and Smith 1986). Dry-weight-rank groups were $P$. smithii, H. comata, C. filifolia, other $\mathrm{C}_{3}$ perennial grasses, $\mathrm{C}_{4}$ perennial grasses, annual grasses, forbs, and shrubs. H. comata was included with other cool season grasses in 2003 and estimated separately thereafter. Species classified as other $\mathrm{C}_{3}$ perennial grasses were $P$. secunda, prairie junegrass (Koeleria macrantha [Ledeb.] Schult.), green needlegrass (Nassella viridula [Trin.] Barkworth), bluebunch wheatgrass (Pseudoroegneria spicata [Pursh] A. Löve), squirreltail (Elymus elymoides [Raf.] Swezey), and crested wheatgrass (Agropyron cristatum [L.] Gaertn.). $C_{4}$ perennial grasses included $B$. gracilis, buffalograss (Buchloe dactyloides [Nutt.] J. T. Columbus), sand dropseed (Sporobolus cryptandrus [Torr.] A. Gray), and perennial threeawn (Aristida purpurea Nutt.). Based on long-term transects at these sites, basal cover of the group we classified as $\mathrm{C}_{4}$ perennial grasses was $81 \%$ B. gracilis and $18 \% B$. dactyloides, and that classified as $\mathrm{C}_{3}$ perennial grasses was $93 \%$ P. secunda and $6 \% \mathrm{~K}$. macrantha. Annual grasses were B. japonicus, B. tectorum, and V. octoflora. Dryweight ranks were estimated in each biomass quadrat before clipping then weighted by quadrat biomass to compute biomass estimates by component.

Minimum, maximum, and daily average soil temperature and soil moisture were analyzed using SAS MIXED ANOVA for a completely randomized design (Littell et al. 1996) with repeated measures. Models included main effects of experiment, fire treatment, and sampling period within the first postfire year and all interactions. Period (weekly average of hourly temperature readings, 2-wk sample of soil moisture) was the repeated measure, and plot was the subject. Variance components and autoregressive order 1 covariance structures were selected based on comparisons of Akaike's information criteria.

To assess site differences between experiments, standing crop data from nonburned plots during 2004 and 2005 were analyzed by herbage component using SAS MIXED ANOVA. Models included terms for experiment, year, and their interaction, and plot was the random effect. Year effects were tested using SAS MIXED ANOVA on grass, forb, A. frigida, and total current-year biomass, root mass, and litter organic matter of nonburned plots from 2004 through 2006. 


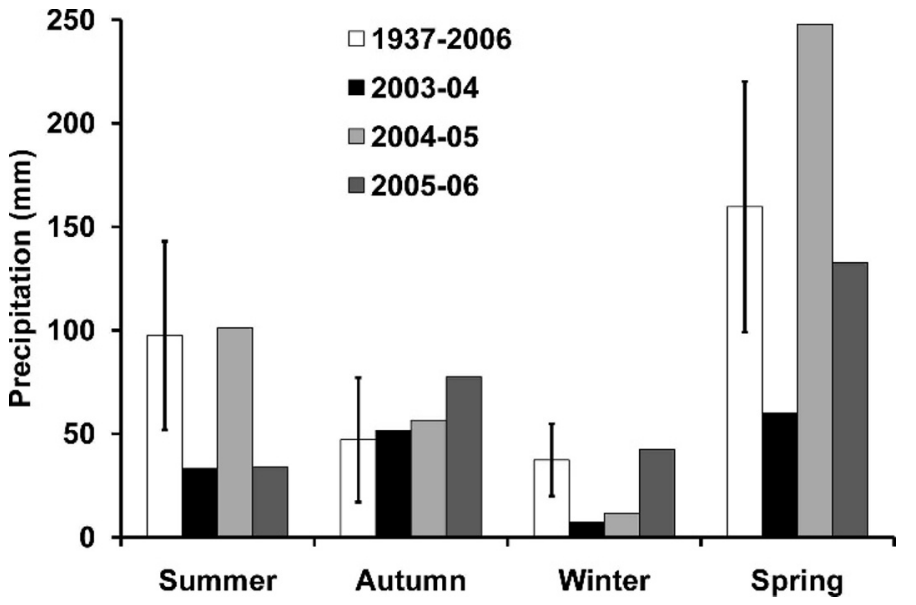

Figure 1. Summer (July-September), autumn (October-December), winter (January-March), and spring (April-June) precipitation for each year of study and the 70-year mean seasonal precipitation ( $\pm 1 \mathrm{SD})$.

Biomass data to determine resistance (one year following fire) to fire treatment were analyzed using SAS MIXED ANCOVA. Models included the main effects of experiment, fire treatment, and their interaction on data from the first year following fire for each experiment. Plot was the random effect, and pre-treatment data were used as the covariate when significant. Pre-treatment data were not used as a covariate for analyses of current-year grass, other $\mathrm{C}_{3}$ perennial grasses, or $H$. comata biomass because no pre-treatment data were collected for current-year grass and $H$. comata and other $\mathrm{C}_{3}$ perennial grasses were not estimated separately for pre-treatment measurements in 2003.

Resilience (two years following fire) was analyzed separately using the same model structure as for resistance tests, except the response variables were from the second growing season following fire. Relative contributions to total standing crop were tested by component using SAS MIXED ANCOVA. Models included the main effects of experiment, fire treatment, time since treatment, and their interactions.

Pre-treatment data were used as the covariate when significant. In all cases, 0.75 -ha plots were the experimental unit. All data were subjected to the Shapiro-Wilk test for normality (Shapiro and Wilk 1965) and were log-transformed before analyses if the normality hypothesis was rejected. Transformed data are presented as back-transformed means with standard errors of the means. The assumption of homogeneous variances in the main plot analysis was tested with Levene's test. Significant interactions were followed by tests of simple effects at $\alpha=0.05$. Tests generating $P$ values between 0.05 and 0.10 are reported and discussed as trends.

\section{RESULTS}

\section{Precipitation and Post-Fire Environment}

Growing conditions, particularly spring precipitation, were very different between experiments during burn treatment years and first post-fire growing seasons. Experiment 1 fires were conducted during the third driest and sixth hottest summer in the previous 70 years and were followed by the driest winter

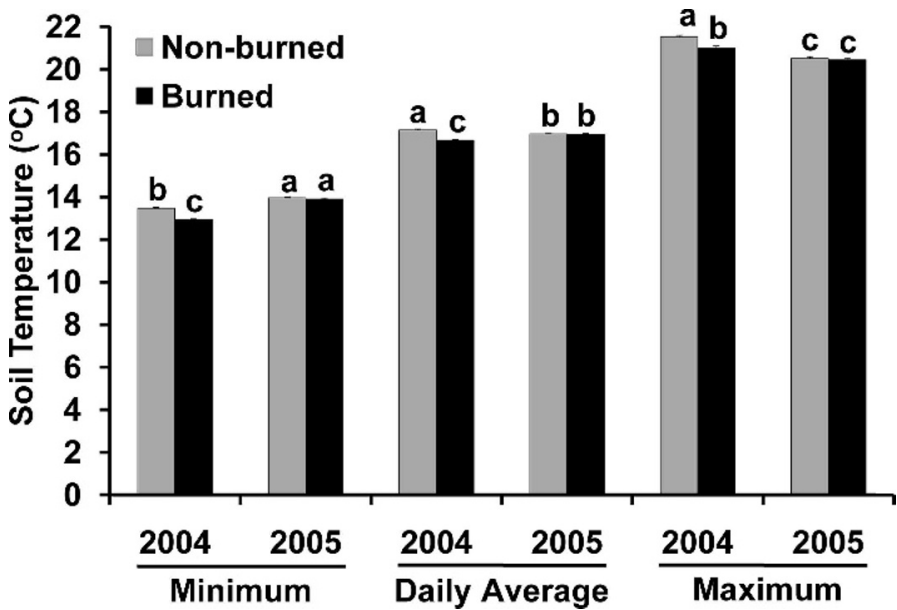

Figure 2. Nonburned and burned site minimum, average, and maximum daily soil temperature (+SE) at $10 \mathrm{~cm}$ depth during 2004 and 2005. Means were calculated from hourly readings 1 April to 18 November the first growing season following summer fire. Means marked with the same letter within minimum, average, and maximum temperature categories are similar $(P<0.05)$.

and second driest spring during that same period (Fig. 1). In contrast, Experiment 2 fires were followed by the fifth wettest spring in 70 years.

As expected, soil temperature varied by year and sampling period. Minimum, daily average, and maximum soil temperatures were warmer on nonburned than burned sites during drought and were similar between treatments during a wet post-fire growing season (Fig. 2). Soil water content varied among sampling periods and between years as well. Of the 16 growing season samples each year, the wetter 2005 growing season had greater soil moisture than 2004 during all but four sampling periods in August and September (Fig. 3). Soil water content was greater on nonburned than burned sites across years and sampling periods (12.07 versus $11.20 \pm 0.19 \%)$.

Sites were similar between experiments in that concurrent measures of standing crops differed between experiment sites for only two components. The site for Experiment 1 had more $\mathrm{C}_{4}$ perennial grasses (266 versus $115 \pm 50 \mathrm{~kg} \cdot \mathrm{ha}^{-1}$ ) and the site for Experiment 2 had more P. smithii $(370$ versus $150 \pm 89 \mathrm{~kg} \cdot \mathrm{ha}^{-1}$ ), based on nonburned plots from each

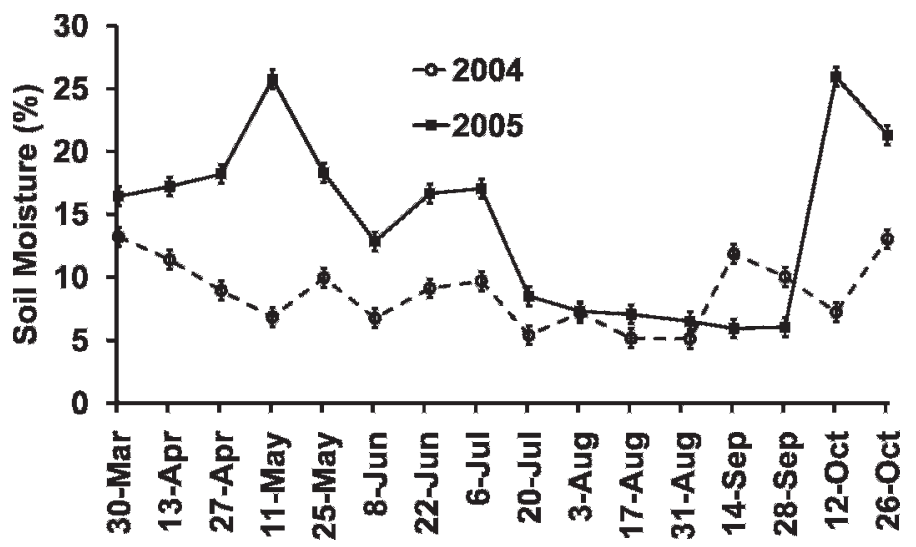

Figure 3. Soil moisture $(+\mathrm{SE})$ across burned and nonburned sites throughout the growing season following fire in 2004 and 2005. 
Table 1. Grass, forb, Artemisia frigida, and total aboveground currentyear biomass, root $(30 \mathrm{~cm})$, and litter organic matter $(0 \mathrm{M})$ mass $\left(\mathrm{kg} \cdot \mathrm{ha}^{-1}\right)$ by component and year for nonburned sites highlighting year (weather) effects. ${ }^{1}$

\begin{tabular}{lrrrr}
\hline & \multicolumn{3}{c}{ Year } & \\
\cline { 2 - 4 } \multicolumn{1}{c}{ Component } & 2004 & 2005 & 2006 & SEM \\
\hline Grass & $268 \mathrm{c}$ & $1280 \mathrm{a}$ & $907 \mathrm{~b}$ & 47 \\
Forb & $25 \mathrm{C}$ & $207 \mathrm{a}$ & $101 \mathrm{~b}$ & 15 \\
Artemisia frigida & $14 \mathrm{~b}$ & $31 \mathrm{ab}$ & $45 \mathrm{a}$ & 9 \\
Total aboveground & $308 \mathrm{C}$ & $1518 \mathrm{a}$ & $1053 \mathrm{~b}$ & 49 \\
Root & $15034 \mathrm{a}$ & $14924 \mathrm{a}$ & $13563 \mathrm{a}$ & 1665 \\
Litter OM & $390 \mathrm{~b}$ & $385 \mathrm{~b}$ & $780 \mathrm{a}$ & 52
\end{tabular}

${ }^{1}$ SEM indicates standard error of the mean. Means within a component followed by the same letter are similar $(P<0.05)$.

experiment during 2004 and 2005. These results indicate that experiment effects or experiment interactions with fire treatment reflect differences in years rather than sites, with the potential exceptions of those for $\mathrm{C}_{4}$ perennial grasses or $P$. smithii. The year effect was strong and presumably weather induced. Current-year grass, forb, and total biomass were each least during the drought of 2004, increased following the wet spring of 2005, and decreased to an intermediate level with the near-average spring precipitation of 2006 (Table 1). Currentyear biomass of $A$. frigida was minor but trended $(P<0.08)$ toward an increase between 2004 and 2006. Root mass was similar across years. Litter organic matter doubled in 2006, reflecting the increased production in 2005.

\section{Resistance}

Fire effects on total and grass standing crops varied by experiment the first growing season following fire (Fig. 4). Fire reduced each standing crop measure about $60 \%$ during drought and had no effect when fire was followed by a wet spring. Fire effects varied by experiment for $P$. smithii and other $\mathrm{C}_{3}$ perennial grasses as well (Fig. 5). During drought, $P$. smithii standing crop was similar between nonburned and burned sites. Pascopyrum smithii standing crop was greater following a wet spring than a dry spring and about $47 \%$ greater for burned than nonburned sites. Other $\mathrm{C}_{3}$ perennial grass standing crop was similar between burned and nonburned sites during each experiment. However, the interacting effects of fire and experiment indicate other $\mathrm{C}_{3}$ perennial grasses were stable between experiments for nonburned sites and more than tripled from the dry conditions of Experiment 1 to the wet conditions of Experiment 2 on burned sites.

The contrast in post-fire spring precipitation also expressed itself with differences between Experiment 1 and Experiment 2 for forbs, H. comata, and annual grasses (Table 2). Fire reduced C. filifolia, annual grass, and forb standing crop, with negative trends for $H$. comata and A. frigida as well. $\mathrm{C}_{4}$ perennial grass standing crop was similar between experiments and between fire treatments. Collectively, standing crop of all $\mathrm{C}_{3}$ perennial grasses was similar between burned and nonburned sites $\left(616 \pm 58 \mathrm{~kg} \cdot \mathrm{ha}^{-1}\right)$. Root mass was similar between experiments and between fire treatments. Fire reduced litter organic matter $57 \%$ across experiments.

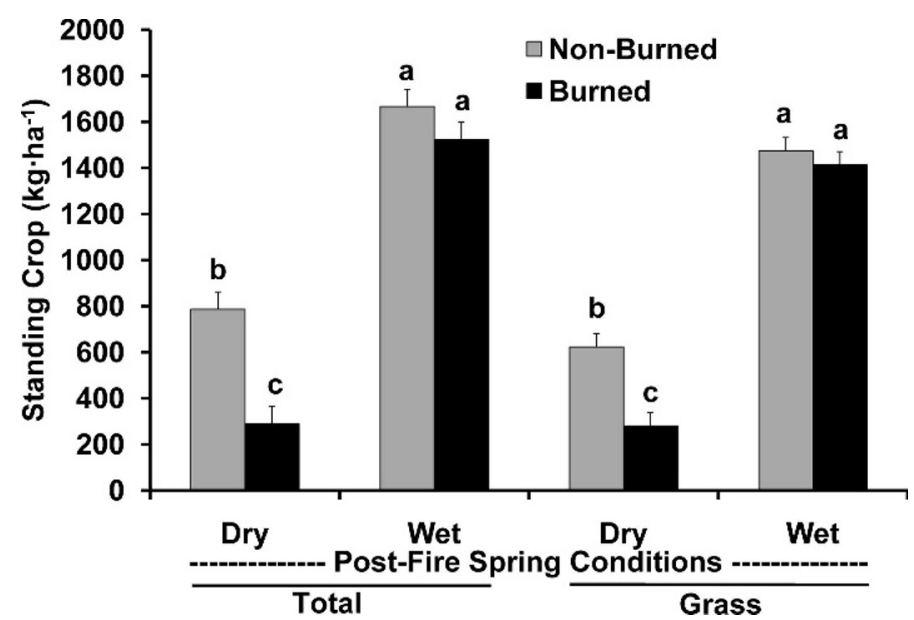

Figure 4. First-year summer fire effects (resistance) on total and grass standing crop (+SE) under the dry post-fire conditions of Experiment 1 and wet post-fire conditions of Experiment 2. Means marked with the same letter within an herbage component are similar $(P<0.05)$.

Current-year grass biomass was similar between burned and nonburned sites $\left(803 \pm 66 \mathrm{~kg} \cdot \mathrm{ha}^{-1}\right)$. Fire caused negative trends in current-year biomass for forbs $(59$ versus $\left.100 \pm 22 \mathrm{~kg} \cdot \mathrm{ha}^{-1} ; P<0.08\right)$ and A. frigida (14 versus $\left.37 \pm 10 \mathrm{~kg} \cdot \mathrm{ha}^{-1} ; P<0.06\right)$. However, the dominance of grasses overwhelmed the trends for forb and A. frigida biomass so that total current-year biomass was similar between burned and nonburned sites $\left(907 \pm 73 \mathrm{~kg} \cdot \mathrm{ha}^{-1}\right)$. Current-year biomass was less during the dry conditions of Experiment 1 than the wet conditions of Experiment 2 for grass $(268$ versus $\left.1337 \pm 46 \mathrm{~kg} \cdot \mathrm{ha}^{-1}\right)$, forbs $\left(25\right.$ versus $\left.134 \pm 15 \mathrm{~kg} \cdot \mathrm{ha}^{-1}\right)$, and total biomass ( 308 versus $1507 \pm 52 \mathrm{~kg} \cdot \mathrm{ha}^{-1}$ ), with a similar trend for A. frigida (14 versus $36 \pm 7 \mathrm{~kg} \cdot \mathrm{ha}^{-1} ; P<0.06$ ).

\section{Resilience}

Total standing crop was similar between fire treatments by the second post-fire growing season (Table 3). Likewise, no fire

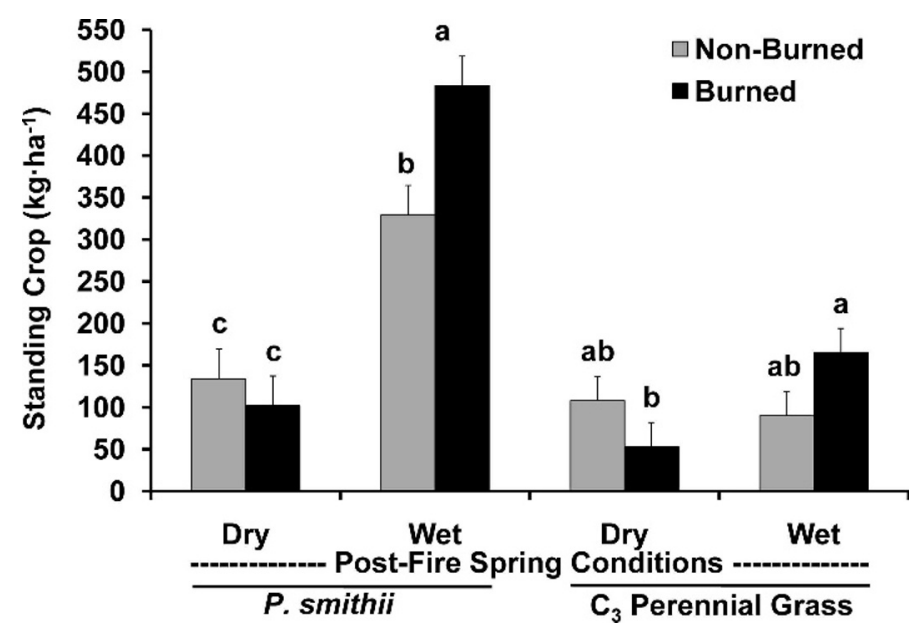

Figure 5. First-year summer fire effects (resistance) on Pascopyrum smithii and other $\mathrm{C}_{3}$ perennial grass (excluding Hesperostipa comata) standing crop (+SE) under the dry post-fire conditions of Experiment 1 and wet post-fire conditions of Experiment 2. Means marked with the same letter within an herbage component are similar $(P<0.05)$. 
Table 2. First-year experiment and summer fire effects (resistance) on biomass $\left(\mathrm{kg} \cdot \mathrm{ha}^{-1}\right)$ of aboveground vegetation component, roots $(30 \mathrm{~cm})$, and litter organic matter (OM).

\begin{tabular}{|c|c|c|c|c|c|c|c|c|}
\hline \multirow[b]{2}{*}{ Biomass component } & \multicolumn{4}{|c|}{ Experiment comparison } & \multicolumn{4}{|c|}{ Fire comparison } \\
\hline & Experiment 1 & Experiment 2 & SE & $P$ value & Nonburned & Burned & SE & $P$ value \\
\hline Hesperostipa comata & 73 & 403 & 47 & 0.0094 & 314 & 163 & 47 & 0.0651 \\
\hline Carex filifolia & 113 & 169 & 26 & 0.5084 & 168 & 115 & 26 & 0.0403 \\
\hline $\mathrm{C}_{4}$ grass & 126 & 165 & 27 & 0.1758 & 169 & 122 & 27 & 0.1052 \\
\hline Annual grass & 9 & 106 & 11 & $<0.0001$ & 67 & 48 & 11 & 0.0330 \\
\hline Forbs & 28 & 140 & 17 & 0.0002 & 103 & 65 & 17 & 0.0139 \\
\hline Artemisia frigida & 32 & 38 & 12 & 0.4270 & 65 & 5 & 13 & 0.0538 \\
\hline Roots & 12493 & 14238 & 1414 & 0.2430 & 14095 & 12636 & 1333 & 0.2973 \\
\hline Litter OM & 275 & 273 & 38 & 0.9661 & 383 & 165 & 34 & $<0.0001$ \\
\hline
\end{tabular}

effects were observed for grass, A. frigida, or forb standing crop. However, differences between experiments continued, with greater forb standing crop during the wet spring of Experiment 1 than the near-average spring of Experiment 2 and a similar trend for total standing crop.

Fire effects were short lived for most components within the grass fraction of the standing crop (Table 3). Standing crops were similar between fire treatments for $H$. comata, other $\mathrm{C}_{3}$ perennial grasses, C. filifolia, and $\mathrm{C}_{4}$ perennial grasses. In contrast, fire effects on $P$. smithii and annual grasses were of greater magnitude the second year following fire than the first. $P$. smithii standing crop more than doubled on burned sites, and annual grass standing crop was more than three times greater on nonburned sites. Annual grass standing crop also differed between Experiments 1 and 2, responding to previous autumn precipitation more so than spring precipitation. Standing crop of all $\mathrm{C}_{3}$ grasses was $78 \%$ greater on burned than nonburned sites (1079 versus $607 \pm 67 \mathrm{~kg} \cdot \mathrm{ha}^{-1}$ ). Root mass was similar between experiments and fire treatments.

Litter organic matter was strongly affected by the increased production during the spring of 2005. Therefore, litter mass was greater for Experiment 2 than Experiment 1 two years after fire (Table 3). Litter mass was still considerably less abundant on burned than nonburned sites during the second post-fire growing season. Burned sites had $43 \%$ as much litter as nonburned sites the first year and $65 \%$ two years after fire, suggesting steady recovery. However, absolute differences between treatments were fairly constant at $218 \mathrm{~kg} \cdot \mathrm{ha}^{-1}$ the first post-fire year and $199 \mathrm{~kg} \cdot \mathrm{ha}^{-1}$ the second post-fire year.

Current-year grass biomass remained similar between fire treatments $\left(1119 \pm 96 \mathrm{~kg} \cdot \mathrm{ha}^{-1}\right)$. Burned sites rebounded from initial negative trends, with burned and nonburned sites having similar amounts of forb $\left(155 \pm 36 \mathrm{~kg} \cdot \mathrm{ha}^{-1}\right)$ and $A$. frigida $\left(36 \pm 13 \mathrm{~kg} \cdot \mathrm{ha}^{-1}\right)$ current-year biomass. Total current-year biomass was also similar between fire treatments $\left(1309 \pm 83 \mathrm{~kg} \cdot \mathrm{ha}^{-1}\right)$. Again, precipitation appeared to have a greater effect than fire, with grass, forb, and total currentyear biomass being 423, 108, and $511 \mathrm{~kg} \cdot \mathrm{ha}^{-1}$ greater, respectively, in Experiment 1 than Experiment 2.

\section{Functional Group Composition}

Fire effects on functional group composition varied with time since fire for H. comata and annual grasses (Fig. 6). Fire

Table 3. Second-year experiment and summer fire effects (resilience) on biomass by aboveground vegetation component, roots ( $30 \mathrm{~cm})$, and litter organic matter (OM). Individual components may not sum to group totals because some means were adjusted using pre-treatment measures as covariates.

\begin{tabular}{|c|c|c|c|c|c|c|c|c|}
\hline \multirow[b]{2}{*}{ Biomass component } & \multicolumn{4}{|c|}{ Experiment comparison } & \multicolumn{4}{|c|}{ Fire comparison } \\
\hline & Experiment 1 & Experiment 2 & SE & $P$ value & Nonburned & Burned & SE & $P$ value \\
\hline Grass & 1458 & 1331 & 115 & 0.2913 & 1320 & 1469 & 115 & 0.2195 \\
\hline Pascopyrum smithii & 371 & 286 & 83 & 0.3331 & 214 & 443 & 75 & 0.0110 \\
\hline Hesperostipa comata & 350 & 386 & 56 & 0.5431 & 338 & 397 & 56 & 0.3154 \\
\hline Other $\mathrm{C}_{3}$ grass & 164 & 103 & 49 & 0.2377 & 90 & 177 & 49 & 0.1035 \\
\hline Carex filifolia & 210 & 113 & 39 & 0.0301 & 152 & 171 & 39 & 0.6178 \\
\hline $\mathrm{C}_{4}$ grass & 338 & 106 & 51 & 0.0007 & 236 & 208 & 51 & 0.5984 \\
\hline Annual grass & 73 & 289 & 67 & 0.0073 & 275 & 87 & 67 & 0.0155 \\
\hline Forb & 211 & 107 & 37 & 0.0147 & 179 & 139 & 37 & 0.2978 \\
\hline Artemisia frigida & 26 & 47 & 13 & 0.1305 & 36 & 38 & 13 & 0.8745 \\
\hline Total aboveground & 1695 & 1485 & 108 & 0.0754 & 1535 & 1646 & 108 & 0.3217 \\
\hline Roots & 13989 & 12846 & 1051 & 0.2997 & 13465 & 13370 & 990 & 0.9258 \\
\hline Litter OM & 297 & 628 & 76 & 0.0009 & 562 & 363 & 76 & 0.0217 \\
\hline
\end{tabular}




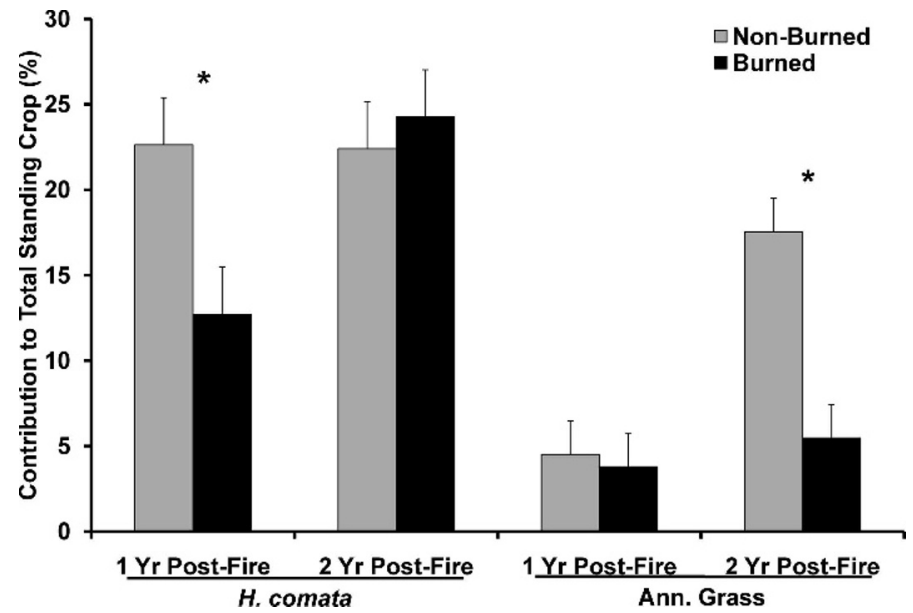

Figure 6. Functional group composition (+SE) of Hesperostipa comata and annual grasses on nonburned and burned sites $1 \mathrm{yr}$ and $2 \mathrm{yr}$ after summer fire. Asterisks denote fire treatment differences $(P<0.05)$ within a component and time since fire.

reduced $H$. comata contributions to total standing crop, but the difference was limited to the first year following fire. Annual grass initially made up a small portion of total standing crop on burned and nonburned sites. The second year after fire annual grass more than tripled on nonburned sites while remaining minor on burned sites. Fire caused considerable changes in functional group composition across experiments and time since fire for $P$. smithii, other $\mathrm{C}_{3}$ perennial grasses, and $A$. frigida (Fig. 7). With fire, P. smithii displaced H. comata as the dominant species and other $\mathrm{C}_{3}$ perennial grass contributions increased to exceed those of annual grasses and forbs. A. frigida was reduced to less than $2 \%$ of the standing crop by summer fire. Percent standing crop composition was similar between burned and nonburned sites across experiments and time since fire for $\mathrm{C}_{4}$ perennial grasses, C. filifolia, and forbs.

\section{DISCUSSION}

This research captured the effects of summer fires occurring during near-average and very dry years followed by extremely dry and extremely wet growing conditions, respectively. Additionally, with both multiple treatment and multiple response years, we were able to address immediate (i.e., firstyear) responses to fire as well as speed and extent of recovery following fire with second-year responses. Fire effects on the soil environment were minor and biomass data indicated northern mixed prairie is resistant to such disturbance. The greatest effects of summer fire were reductions in litter, reductions in nonnative annual grasses, and increases in $\mathrm{C}_{3}$ perennial grasses.

Data did not fully support the hypothesis that fire would reduce daily minimum soil temperature and increase daily maximum soil temperature. Cooler minimum temperatures on burned sites in Experiment 1 suggested fire may have reduced the insulating effects of litter and standing vegetation. However, the difference was only about $0.5^{\circ} \mathrm{C}$ and consistent for average and maximum temperatures as well. It is possible that burned sites experienced more convective cooling than

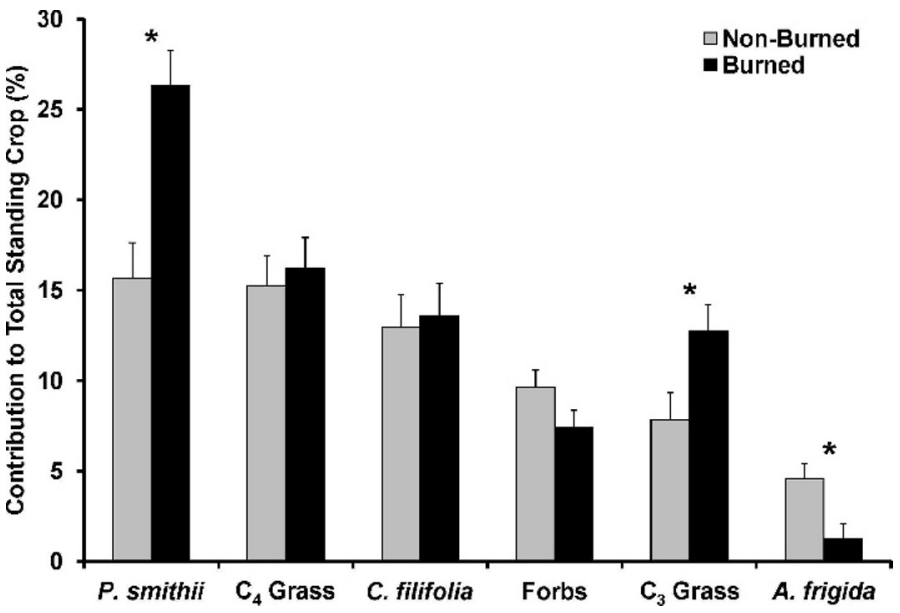

Figure 7. Functional group composition (+SE) on nonburned and burned sites across years after summer fire. Asterisks denote fire treatment differences $(P<0.05)$ within a component.

nonburned sites (Knapp 1984), but doubtful that such effects would surmount those of increased solar radiation. Additionally, minimum, maximum, and average soil temperatures were similar between burned and nonburned sites in Experiment 2 . Daytime soil temperatures have generally been greater on burned sites (Hulbert 1969; Sharrow and Wright 1977; Ewing and Engle 1988; Bremer and Ham 1999; Vermeire et al. 2005). This discrepancy can be partially explained by differences in productivity, timing of measurement relative to fire, and soil color. Productive grasslands, such as tallgrass prairie, have much more litter and standing vegetation than semiarid grasslands, making the contrast in insolation and insulation between burned and nonburned sites greater. Similarly, the amount of black residue we observed was minor compared to more productive systems and much of the post-fire warming of soils has been explained by increased insolation with reduced albedo (Ewing and Engle 1988; Bremmer and Ham 1999). Because we measured soil temperature during the growing season following summer fire, beginning 7 mo later, most of the residue had been removed by precipitation or wind. Additionally, our surface soils are relatively light colored, similar to that of recent dead plant material when dry. Finally, we sampled soil temperature at $10 \mathrm{~cm}$ to assess responses near the midpoint of root mass. Observations of increased soil temperature following fire have typically been at shallower depths where sensitivity to temperature change is greater.

Burned sites were drier than nonburned sites as hypothesized. However, the difference was consistently less than $1 \%$ throughout the April through October period and across both experiments. Changing cover and canopy structure during the growing season and the dramatic differences in spring precipitation between experiments had no apparent effect on differences between burned and nonburned sites. In fact, the extreme conditions may have moderated the effects of litter loss in that there was little moisture to retain during the drought and ample moisture during much of the wet spring. Reduced soil moisture cannot be attributed to differences in plant growth because plant production was similar between fire treatments and soil moisture did not diverge during the growing season. Nor were differences caused by fire-induced 
shifts in species composition from dominance of more waterefficient species to less water-efficient species. Others have indicated that plants on burned sites experience greater water stress than those on nonburned sites (Redmann 1978), but that relationship can shift from less stress early in the growing season to greater stress late in the growing season (Knapp 1984).

Reduced soil water content has been attributed to increased evaporative losses from the soil with reduced litter and canopy cover (Willms et al. 1993). However, the relationship between litter and soil moisture will depend on litter quantity and type of precipitation events as litter can intercept significant amounts of precipitation if litter is excessive or precipitation events are generally small (Naeth et al. 1991). Fire reduced litter for at least two years, but biomass, and likely canopy cover, were similar with the exception of the first year in Experiment 1 . The drier soils in burned sites during early April indicates the effect was expressed during the period between the fires and the first spring measurement. Snow depth was not measured, but we observed less snow on burned sites. Others have reported similar findings (Trlica and Schuster 1969; de Jong and MacDonald 1975), which may be important in regions where snow can provide significant contributions to annual precipitation (Hatfield et al. 2001). Autumn plant growth was minimal if not nonexistent, so reduction of snow capture on burned sites appeared the likely cause of drier soils.

Although grass and total standing crop were affected by fire, the similarity between fire treatments for current-year biomass indicated differences were from removal of standing dead material rather than reductions in productivity. Resistance to summer fire was further marked by similarity in root biomass between burned and nonburned sites. Even initial negative trends in current-year biomass for forbs and A. frigida were quickly reversed. Differences between standing dead material on burned and nonburned sites may be maximized if sites are not grazed and good growing conditions are followed by drought. Likewise, differences in standing dead should be minimized if sites are heavily grazed and drought is followed by good growing conditions. The first scenario, similar to that observed in our Experiment 1, increases accumulation of standing dead whereas the second scenario reduces accumulation of standing dead. Therefore, we observed a fire-induced reduction in total standing crop only under conditions promoting a maximum contrast between burned and nonburned sites. Nonetheless, the loss of standing dead material represents a temporary loss of forage and protective cover following fire, even though productivity is stable.

Standing dead material and litter affect availability of light and water. Increased light availability after fire has explained part of the positive growth response to fire in mesic grasslands (Knapp 1984). However, productivity for semiarid grasslands is often water-limited rather than light limited. Despite sharp fire-induced reductions in litter and standing dead material, burned sites were only slightly drier than nonburned sites, and the relationship was similar over the course of the growing season. Our data indicate similar litter mass could be expected between burned and nonburned sites within 3-4 yr after fire and standing dead was similar by the first or second growing season after fire. Dix (1960) observed litter structure being regained 4 yr after summer wildfire in the northern Great Plains when livestock had access to burned sites.

Current-year and old standing dead were separated for grass biomass, but not by individual components within the grass fraction. Therefore, one must recognize that in the first year after fire, comparisons represent current-year biomass of burned sites versus current-year and old standing dead on nonburned sites. This may explain the rapid reduction and increase in $H$. comata as reflecting primarily the initial combustion of standing dead material and subsequent growth sufficient to match old and new biomass on nonburned sites. Likewise, similarity of other $\mathrm{C}_{3}$ grass biomass between fire treatments the first year after fire indicates predominantly current-year biomass on burned sites was equivalent to the combined current and old biomass on nonburned sites that had not been grazed for 2 yr. Similarity in current-year grass biomass between burned and nonburned sites was likely due to a reduction of annual grasses offsetting an increase in $\mathrm{C}_{3}$ perennial grasses on burned sites.

The $\mathrm{C}_{3}$ perennial grasses became more dominant on burned sites as hypothesized, particularly with the contributions from P. smithii. This shift was due to increased $\mathrm{C}_{3}$ perennial grass production and compounded by the reduction of annual grasses. Autumn and spring fire have been shown to reduce the dominant annual grass Bromus japonicus (White and Currie 1983; Whisenant and Uresk 1990; Whisenant 1990), and its seeds have been proven vulnerable to fire-induced mortality (Vermeire and Rinella 2009). The exception within the $\mathrm{C}_{3}$ perennial grasses, a short-term reduction in $H$. comata, could have been expected as others have noted the species to be sensitive to damage from fire (Wright and Klemmedson 1965; Wright 1971). Caespitose grasses tend to be more vulnerable to fire than rhizomatous species because their meristems are exposed in the crown, and they accumulate fuel that may burn hotter and longer (Wright 1971; Ewing and Engle 1988; Engle et al. 1998). $C_{4}$ perennial grasses were not reduced as observed following summer fire in more mesic or $\mathrm{C}_{4}$-dominated mixed prairie (Howe 1995; Engle et al. 1998; Brockway et al. 2002; Ansley et al. 2006; Ford and Johnson 2006). The $C_{4}$ grasses were growing or green during fires of other studies but were generally inactive when our fires were ignited and typically are so during late summer in dry northern mixed prairie.

Spring and autumn fire effects on productivity in the region have been variable, with losses for 1 to $3 \mathrm{yr}$, no change, or modest increases (White and Currie 1983; Engle and Bultsma 1984; Whisenant and Uresk 1989, 1990; Redmann et al. 1993; Shay et al. 2001). Scheintaub et al. (2009) reviewed research of fire effects throughout the western Great Plains and determined more than half reported reduced productivity and only $15 \%$ reported greater productivity following fire. Although plant response is undoubtedly affected by post-fire precipitation, much of the discrepancy may be driven by seasonality of fire. The lack of change in current-year aboveground biomass or root biomass indicates mixed prairie productivity is resistant to summer fire in the semiarid northern Great Plains. Results are strengthened by their consistency across sharply contrasting post-fire weather conditions. Aside from annual grasses, each component was resilient, with standing crop equaling or exceeding that of nonburned sites by the second growing season following fire. Results indicate biomass was more responsive to 
precipitation than fire and the fire-induced changes in species composition suggest that long-term exclusion of fire may have been a greater disturbance than summer fire.

\section{IMPLICATIONS}

Early research suggested more than 3 yr may be required for northern mixed prairie to recover following fire (Clarke et al. 1943; Dix 1960; Coupland 1973), and results were taken to mean fire had little benefit for herbaceous species (Wright and Bailey 1982). However, our results indicate neither aboveground or belowground productivity were reduced by summer fire whether post-fire spring precipitation was abundant or severely limited. Summer fire shifted northern mixed prairie species composition, reducing nonnative annual grasses and increasing dominance of native $\mathrm{C}_{3}$ perennial grasses. Fireinduced differences in forage availability were limited to losses of standing dead material from previous years' production. The magnitude of such differences would depend on a site's ability to accumulate standing dead material and management factors affecting the amount of standing dead carried over between years. Fire reduced litter, but effects did not translate into large changes in soil moisture or temperature. Although fire did not increase productivity as commonly observed in mesic $\mathrm{C}_{4^{-}}$dominated grasslands, maintenance of productivity through the reduction of nonnative annual plants and increase in native perennials indicates summer fire is an important process for sustaining the integrity of northern mixed prairie.

\section{ACKNOWLEDGMENTS}

The authors appreciate Jennifer Muscha and Aaron Roth for their assistance with data collection and treatment implementation. We are grateful for review comments from Jon Bates and Justin Derner.

\section{LITERATURE CITED}

Ansley, R. J., M. J. Castellano, and W. E. Pinchak. 2006. Sideoats grama growth response to seasonal fires and clipping. Rangeland Ecology \& Management 59:258-266.

Biondini, M. E., A. A. Steuter, and C. E. Grygiel. 1989. Seasonal fire effects on the diversity patterns, spatial distribution and community structure of forbs in northern mixed prairie, USA. Vegetatio 85:21-31.

Bremer, D. J., AND J. M. Ham. 1999. Effect of spring burning on the surface energy balance in a tallgrass prairie. Agricultural and Forest Meteorology 97:43-54.

Brockway, D. G., R. G. Gatewood, and R. B. Paris. 2002. Restoring fire as an ecological process in shortgrass prairie ecosystems: initial effects of prescribed burning during the dormant and growing seasons. Journal of Environmental Management 65:135-152.

Castellano, M. J., and R. J. Ansley. 2007. Fire season and simulated grazing differentially affect the stability and drought resilience of a $\mathrm{C}_{4}$ bunchgrass, $\mathrm{C}_{3}$ bunchgrass and $\mathrm{C}_{4}$ lawngrass. Journal of Arid Environments 69:375-384.

Clarke, S. E., E. W. Tisdale, and N. A. Skoglund. 1943. The effects of climate and grazing on shortgrass prairie vegetation. Ottawa, Canada: Ministry of Agriculture. Canadian Dominion Department of Agriculture Technical Bulletin 46. 53 p.

Coupland, R. T. 1973. Producers: I. Dynamics of above-ground standing crop. Matador Project. Saskatoon, Canada: Canadian IBP, IBP Program Technical Report 27. 159 p.
Debano, L. F. 2000. The role of fire and soil heating on water repellency in wildland environments: a review. Journal of Hydrology 231:195-206.

de Jong, E., AND K. B. MacDonald. 1975. Soil-moisture regime under native grassland. Geoderma 14:207-221.

Dix, R. L. 1960. The effects of burning on the mulch structure and species composition of grasslands in western North Dakota. Ecology 41: 49-56.

Engle, D. M., And T. G. Bidwell. 2001. The response of central North American prairies to seasonal fire. Journal of Range Management 54:2-10.

Engle, D. M., And P. M. Bultsma. 1984. Burning of northern mixed prairie during drought. Journal of Range Management 37:398-401.

Engle, D. M., R. L. Mitchell, and R. L. Stevens. 1998. Late growing-season fire effects in mid-successional tallgrass prairies. Journal of Range Management 51:115-121.

Erichsen-Arychuk, C., E. W. Bork, and A. W. Balley. 2002. Northern dry mixed prairie responses to summer wildlife and drought. Journal of Range Management 55:164-170.

Ewing, A. L., And D. M. Engle. 1988. Effects of late summer fire on tallgrass prairie microclimate and community composition. American Midland Naturalist 120:212-223.

Ford, P. L., AND G. V. Johnson. 2006. Effects of dormant- vs. growing-season fire in shortgrass steppe: biological soil crust and perennial grass responses. Journal of Arid Environments 67:1-14.

Gillen, R. L., And E. L. Smith. 1986. Evaluation of the dry-weight-rank method for determining species composition in tallgrass prairie. Journal of Range Management 39:283-285.

Govender, N., W. S. W. Trollope, and B. W. Van Wilgen. 2006. The effect of fire season, fire frequency, rainfall and management on fire intensity in savanna vegetation in South Africa. Journal of Applied Ecology 43:748-758.

Grime, J. P. 2001. Plant strategies, vegetation processes, and ecosystem properties. 2nd ed. New York, NY, USA: John Wiley \& Sons. 417 p.

Hatfield, J. L., T. J. Sauer, and J. H. Prueger. 2001. Managing soils to achieve greater water use efficiency: a review. Agronomy Journal 93:271-280.

Heitschmidt, R. K., and L. T. Vermelre. 2005. An ecological and economic risk avoidance drought management decision support system. In: J. A. Milne [ED.]. Pastoral systems in marginal environments. XXth International Grasslands Congress; 26 June-1 July; Dublin, Ireland. 178 p.

HIGGINS, K. F. 1984. Lightning fires in North Dakota grasslands and in pine-savanna lands of South Dakota and Montana. Journal of Range Management 37:100-103.

Howe, H. F. 1994. Managing species diversity in tallgrass prairie: assumptions and implications. Conservation Biology 8:691-704.

HowE, H. F. 1995. Succession and fire season in experimental prairie plantings. Ecology 76:1917-1925.

HulberT, L. C. 1969. Fire and litter effects in undisturbed bluestem prairie in Kansas. Ecology 50:874-877.

Jones, R. M., and J. N. G. Hargreaves. 1979. Improvements to dry-weight-rank method for measuring botanical composition. Grass and Forage Science 34:181-189.

KnaPP, A. K. 1984. Post-burn differences in solar radiation, leaf temperature and water stress influencing production in a lowland tallgrass prairie. American Journal of Botany 71:220-227.

Littell, R. C., G. A. Milliken, W. W. Stroup, and R. D. Wolfinger. 1996. SAS system for mixed models. Cary, NC, USA: SAS Institute. 633 p.

Mannetje, L., And K. P. Haydock. 1963. The dry-weight-rank method for botanical analysis of pasture. Journal of the British Grassland Society 18:268275.

Naeth, M. A., A. W. Bailey, D. S. Chanasyk, and D. J. Pluth. 1991. Water holding capacity of litter and soil organic matter in mixed prairie and fescue grassland ecosystems of Alberta. Journal of Range Management 44:13-17.

Redmann, R. E. 1978. Plant and soil water potentials following fire in a northern mixed grassland. Journal of Range Management 31:443-445.

Redmann, R. E., J. T. Romo, and B. Pylypec. 1993. Impacts of burning on primary productivity of Festuca and Stipa-Agropyron grasslands in central Saskatchewan. American Midland Naturalist 130:262-273. 
Scheintaub, M. R., J. D. Derner, E. F. Kelly, and A. K. Knapp. 2009. Response of the shortgrass steppe plant community to fire. Journal of Arid Environments 73:1136-1143.

ShapIRO, S. S., AND M. B. WiLK. 1965. An analysis of variance test for normality (complete samples). Biometrika 52:591-611.

Sharrow, S. H., AND H. A. Wright. 1977. Effects of fire, ash, and litter on soil nitrate, temperature, moisture and Tobosa-grass production in rolling plains. Journal of Range Management 30:266-270.

Shay, J., D. Kunec, and B. Dyck. 2001. Short-term effects of fire frequency on vegetation composition and biomass in mixed prairie in south-western Manitoba. Plant Ecology 155:157-167.

Smart, A. J., B. H. Dunn, P. S. Johnson, L. Xu, and R. N. Gates. 2007. Using weather data to explain herbage yield on three Great Plains plant communities. Rangeland Ecology \& Management 60:146-153.

SteUter, A. A. 1987. C3/C4 production shift on seasonal burns: northern mixed prairie. Journal of Range Management 40:27-31.

Thonicke, K., S. Venevsky, S. Sitch, and W. Cramer. 2001. The role of fire disturbance for global vegetation dynamics: coupling fire into a dynamic global vegetation model. Global Ecology and Biogeography 10:661-677.

Trlica, M. J., And J. L. Schuster. 1969. Effects of fire on grasses of Texas high plains. Journal of Range Management 22:329-333.

Vermelire, L. T., R. K. Heitschmidt, and M. R. Haferkamp. 2008. Vegetation response to seven grazing treatments in the northern great plains. Agriculture Ecosystems and Environment 125:111-119.

Vermeire, L. T., R. B. Mitchell, S. D. Fuhlendorf, and R. L. Gillen. 2004. Patch burning effects on grazing distribution. Journal of Range Management 57:248-252.
Vermeire, L. T., and M. J. Rinella. 2009. Fire alters emergence of invasive plant species from soil surface-deposited seeds. Weed Science 57:304-310.

Vermeire, L. T., D. B. Wester, R. B. Mitchell, and S. D. Fuhlendorf. 2005. Fire and grazing effects on wind erosion, soil water content, and soil temperature. Journal of Environmental Quality 34:1559-1565.

Westerling, A. L., A. Gershunov, T. J. Brown, D. R. Cayan, and M. D. Dettinger. 2003. Climate and wildfire in the western United States. Bulletin of the American Meteorological Society 84:595-604.

Whisenant, S. G. 1990. Postfire population dynamics of Bromus japonicus. American Midland Naturalist 123:301-308.

Whisenant, S. G., and D. W. Uresk. 1989. Burning upland mixed prairie in Badlands National Park. Prairie Naturalist 21:221-227.

Whisenant, S. G., AND D. W. URESK. 1990. Spring burning Japanese brome in a western wheatgrass community. Journal of Range Management 43:205-208.

White, R. S., And P. O. Currie. 1983. Prescribed burning in the northern Great Plains: yield and cover responses of 3 forage speices in the mixed grass prairie. Journal of Range Management 36:179-183.

Willms, W. D., S. M. McGinn, and J. F. Dormaar. 1993. Influence of litter on herbage production in the mixed prairie. Journal of Range Management 46:320-324

WRight, H. A. 1971. Why squirreltail is more tolerant to burning than needle and thread. Journal of Range Management 24:277-284.

Wright, H. A., AND A. W. Balley. 1982. Fire ecology: United States and southern Canada. New York, NY, USA: John Wiley \& Sons. 501 p.

Wright, H. A., And J. O. KLemmedson. 1965. Effect of fire on bunchgrasses of the sagebrush-grass region in southern Idaho. Ecology 46:680-688. 